\title{
The Effect of Maternal Obesity on the Placental Histology
}

\author{
Harith Ali $^{\star}$, Luma Al-Allaf ${ }^{\star \star}$ \\ *Postgraduate Student, Department of Anatomy, College of Medicine University of Mosul , \\ ${ }^{* \star}$ Department of Anatomy, College of Medicine, University of Mosul, Mosul, Iraq \\ Correspondence: harithalali2019@gmail.com
}

(Ann Coll Med Mosul 2020; 42 (2):148-156).

Received: $3^{\text {rd }}$ July. 2020; Accepted: $13^{\text {th }}$ Sept. 2020.

\begin{abstract}
Background: Obesity becomes one of the most universal medical problems that affects women at reproductive period. It has a complicated drawback on mother and child health.

Aims: To evaluate the placental histological changes of obese mothers in comparison to pregnant women with normal body mass index.

Methods: This work is a prospective case- control study in which the placentae were obtained from 40 singleton pregnant women who delivered at Al-Khansaa Maternity Teaching Hospital, Mosul, Northern of Iraq, starting from December 2019 to February 2020. The women were classified into two groups: Group 1 which includes 20 women with BMI ranged between $18-24.9 \mathrm{~kg} / \mathrm{m}^{2}$, Group 2 which includes 20 women with $\mathrm{BMI} \geq 30$. Two placental biopsies were obtained from maternal side and fetal side of each case and prepared for histological examination via light microscope.

Results: The histological examination of placental sections obtained from obese mothers showed several placental changes compared to those of control group. The most frequent feature among these sections is the presence of syncytial knotting in 13(65\%) out of 20 placentae. In addition, features of hypovascular villi, villous fibrinoid necrosis are noticed in $10(50 \%)$ of these specimens, while thickening of trophoblastic basement membrane was noticed in $9(45 \%)$ of these sections. On the other hand, the histological examination of placental sections obtained from obese mothers revealed presence of perivillous fibrin deposition which appeared in $10(50 \%)$ of these sections .Features of stromal fibrosis were noticed in $(40 \%)$ of sections. Other placental changes seen in placental sections obtained from obese mothers include presence of nucleated red blood cells (NRBC) in fetal capillaries, chorangiosis, villous edema, paucity of vasculosyncytial membrane (VSM), inflammation, apoptosis and decidual fibrinoid necrosis.

Conclusion: this work revealed a marked increase in the frequencies of different placental changes in obese mothers in comparison with controls. Further studies are recommended to clarify the exact mechanisms that stand behind these histological changes.
\end{abstract}

Keywords: Placenta, obesity, histological changes.

$$
\begin{aligned}
& \text { تأثير سمنة الامهات على نسيج المشيمة }
\end{aligned}
$$

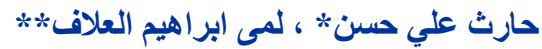

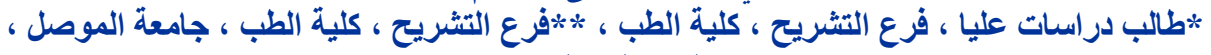

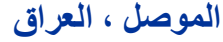

الخلقية: السمنة هي واحدة من أكثر المشاكل الطبية انتشار التي تؤثر على الإنجاب و التي لها نتائج سلبية معقدة على الام والطفل

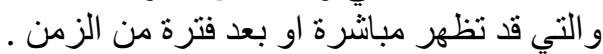

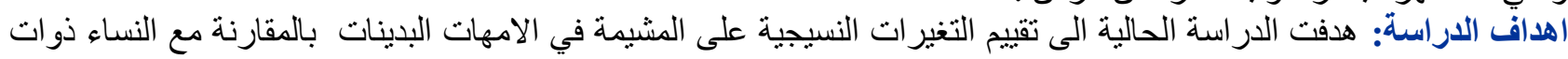

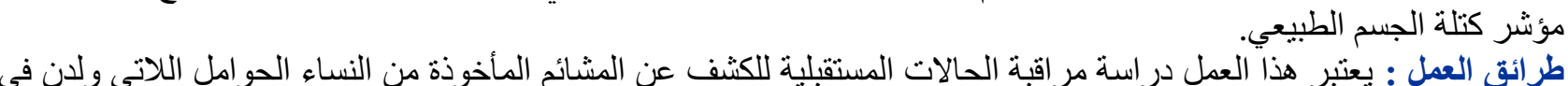

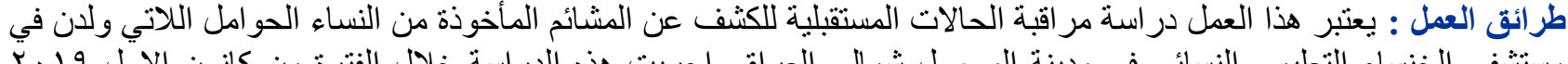

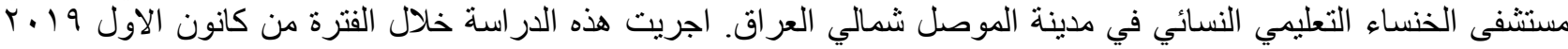

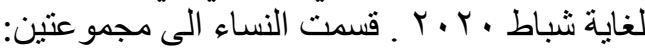

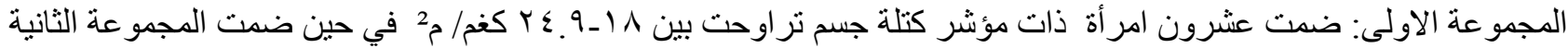

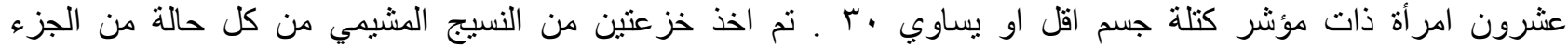


الرحمي(الغشاء الساقط) والجزء الجنيني( الصفيحة المشيمية). مررت العينات بالطريقة النسيجية الروتينية وتم فحصها تحت المجهر الضوئي.

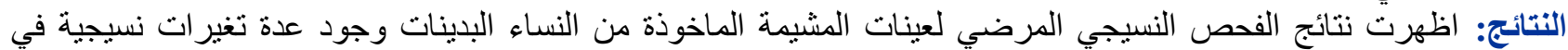

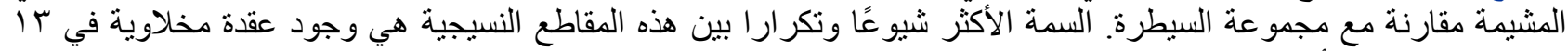

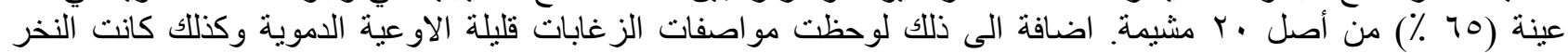

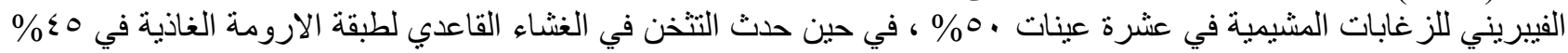

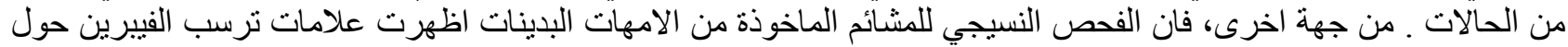

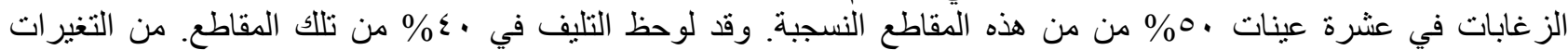

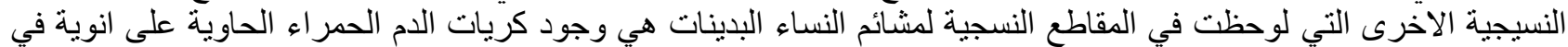

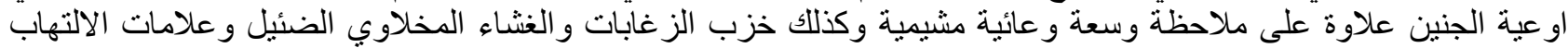

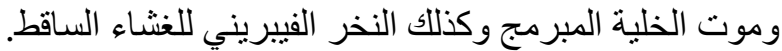

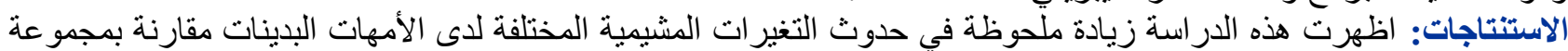

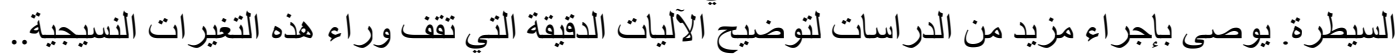

الكلمات المفتاحية: المشيمة، السمنة، التغيرات النسيجية .

\section{INTRODUCTION}

besity is among rapid raising medical issues that affect women at reproductive periods ${ }^{1}$. A marked increase in obesity has been shown during last few decades. Modification in life style, advances in economic state and technologies have resulted in an abundance of nonexpensive high calory diet with a decrease in physical activities.Food consuming by the people is higher with a decrease in their movements.

Maternal obesity is defined as body mass index (BMI) $>30 \mathrm{kilogram} / \mathrm{square}$ meter $\left(\mathrm{kg} / \mathrm{m}^{2}\right)$ that is reported in the first antenatal visit ${ }^{2}$. Universally the epidemiology of obesity has been increased, and the prevalence of overweight and obese women of reproductive age also increases in comparison with those of normal weight ${ }^{3}$.

In the United States the prevalence of obesity in adult women was $35.8 \%$ in $2009-2010^{4}$. In 2006 according to the Iraqi Ministry of Health report the prevalence of obese adult women was $38.2 \%{ }^{5}$. Moreover the obese adult women percentage increased from 23-25 in Baghdad from1997 to $2007^{6,7}$

Obesity can spread to the offspring through bad behavioral effect ${ }^{8}$. It is the most common health problem in adult women and pregnants. It has a complicated drawback on mother and child ${ }^{9}$.

Infertility, spontaneous abortion, congenital anomalies and placental insufficiency were occurred in obese women in early gestation ${ }^{10,11}$.

Obese women are mostly suffered from the gestational metabolic syndrome including inflammation, hypertension, pre-eclampsia, and nutrient metabolism disturbance ${ }^{12}$.

Also Obesity is the strongest causative factor of gestational diabetes mellitus (GDM) ${ }^{13}$, inflammation, increase oxidative stress and hyperinsulinemia this results from increased pregestational insulin resistance in obese mothers which may lead to early fetal and placental disturbances ${ }^{14}$.

Unfortunately, placenta is the least organ that has been studied in cases of obesity, so more knowledge is required to understand the mechanism responsible for fetal and maternal sequel. The placental site and function play an important role in maintenance of fetal life, development and growth, there are different intrauterine factors of fetal and maternal blood circulation that lead to histopathological changes of placenta ${ }^{15}$. Over the last decades, the normal placental weight has increased and that may be due to the increase in the rates of obesity. Several macroscopic and structural finding have been shown in placentae of obese mothers ${ }^{16-18}$.

The principal pathological features of placentae obtained from obese women are increased inflammation ${ }^{19,20}$, accelerated villous maturation (AVM) or delayed villous maturation (DVM) ${ }^{21}$.

Little is known about the placental changes of obese mothers. There is a need to focus a light on these changes and to understand the pathogenesis underlying them. So the aim of this study is to evaluate the placental histological changes of obese mothers in comparison with those of women with normal body mass index. 


\section{SUBJECTS, MATERIALS, And METHODES}

This work is a prospective case- control study that examined placentae which were obtained from 40 singleton pregnant women who delivered at $A L$ Khansaa Maternity Teaching Hospital in Mosul city in north of Iraq. This study was started from December 2019 to February 2020. Ethical approval was obtained from Committee of Ethics at Nineva Health Directorate, Mosul /Iraq. Depending on a history was obtained from women, The gestational age was calculated depending on last menstrual period or the early ultrasonographic examination report. Pregnant women with non-gestational diabetes mellitus, essential hypertension, abruption placenta, multiple pregnancy, smoking and $\mathrm{Rh}$-ve blood group were excluded.

According to their BMI, the women were classified into two groups as follows:

1-Group 1. (Control): Includes 20 women with $\mathrm{BMI}$ ranged between $18-24.9 \mathrm{~kg} / \mathrm{m}^{2}$.

2-Group 2. (Obese) Includes 20 women with BMI $\geq 30 \mathrm{~kg} / \mathrm{m}^{2} 22$.

$\mathrm{BMI}$ of each mother was calculated via dividing the weight in kilogram $(\mathrm{Kg})$ by height in square meter $\left(\mathrm{M}^{2}\right)^{22}$. The weight was obtained according to methods described by Davis et al. and Al-Kubaisy et al. by subtracting $12.5 \mathrm{~kg}$ from the current weight ${ }^{2,5}$. Two biopsies of placental tissue were obtained from maternal side (decidua) and fetal side (chorionic plate) and were prepared for histological examination after staining with (H\&E) using light microscope ${ }^{23-25}$.

According to criteria of Amsterdam Placental Workshop Group 26, Placental lesions are classified into three categories: placental stromalvascular lesions which include (malperfusion, infarction, villous maturation disorder, villous edema), inflammatory lesions which include (villitis and deciduitis) and other placental lesions which include (increase nucleated red blood cells and perivillous fibrin deposition).

The statistical analysis of data was done using excel program and SPSS (version). To compare the frequencies of different placental lesions between two groups chi square $\left(X^{2}\right)$ was used, were $P$ value $<0.05$ was considered as significant $^{27}$.

\section{RESULTS}

This study has examined placentae from 40 women who were categorized into two groups. The maternal clinical characteristics of all cases are shown in Table1.

The light microscopical examination of sections obtained from the fetal surface of placental disc of control group(Group1) using H\&E preparation, showed that each chorionic villous with normal histology as vascular stroma lined or covered with multinucleated syncytiotrophoblastic layer with indistinct cell boundaries and dark stained nuclei with occasional inconspicuous cytotrophoblastic cells (Figure 1). While the microscopical examination of sections from the maternal surface of this group showed normal appearance of maternal decidual cells (Figure 2).

On the other hand, the present study revealed that the histopathological examination of placental sections obtained from obese mothers (Group 2) showed several placental changes compared to those of control group. Table 2.

The most frequent feature among these sections is the presence of syncytial knotting in $13(65 \%)$ out of 20 placentae. (Figure 3).In addition, features of hypovascular villi are noticed in $10(50 \%)$ of these sections (Figures 3\&4). hypovascular villi are small villi and it have decrease numbers and small diameter capillaries or in some sections there is absent of capillaries (avascular villi)

Moreover, villous fibrinoid necrosis occurs in 10 $(50 \%)$ of placental sections of obese mothers (Figure 6), while thickening of trophoblastic basement membrane occurs in $9(45 \%)$ of these sections. (Figure 5).

On the other hand, the histopathological examination of placental sections obtained from obese mothers (group2) revealed presence of perivillous fibrin deposition which was appeared in $10(50 \%)$ of these sections (Figure 6) .Features of stromal fibrosis were noticed in $8(40 \%)$ of sections. (Figures 6\&7).

The present study revealed that the histopathological examination of placental sections obtained from obese mothers (group2) showed presence of nucleated red blood cells (NRBC) in fetal capillaries and this finding was identified in7 $(35 \%)$ of these sections .(Figures 7\&8), while features of chorangiosis was found in $4(20 \%)$ of these sections.(Figure 9). histologically appear as ten or more capillaries in ten or more terminal villi in ten or more areas in placenta use microscopic examination with 10x objective.

Features of villous edema was shown in $4(20 \%)$ out of 20 placentae of group2. (Figure 10). On the other hand, paucity of vasculosyncytial membrane VSM was found in $35 \%$ of sections of obese mothers. (Figure 11).

This study observed features of villitis in $4(20 \%)$ out of 20 placental sections that belong to obese mothers. (Figure 12), while deciduitis was noticed in $7(35 \%)$ of these sections. (Figure 12$)$.

The classification of various placental histological changes in both groups according to criteria of Amsterdam Placental Workshop Group was shown in Table 3. 


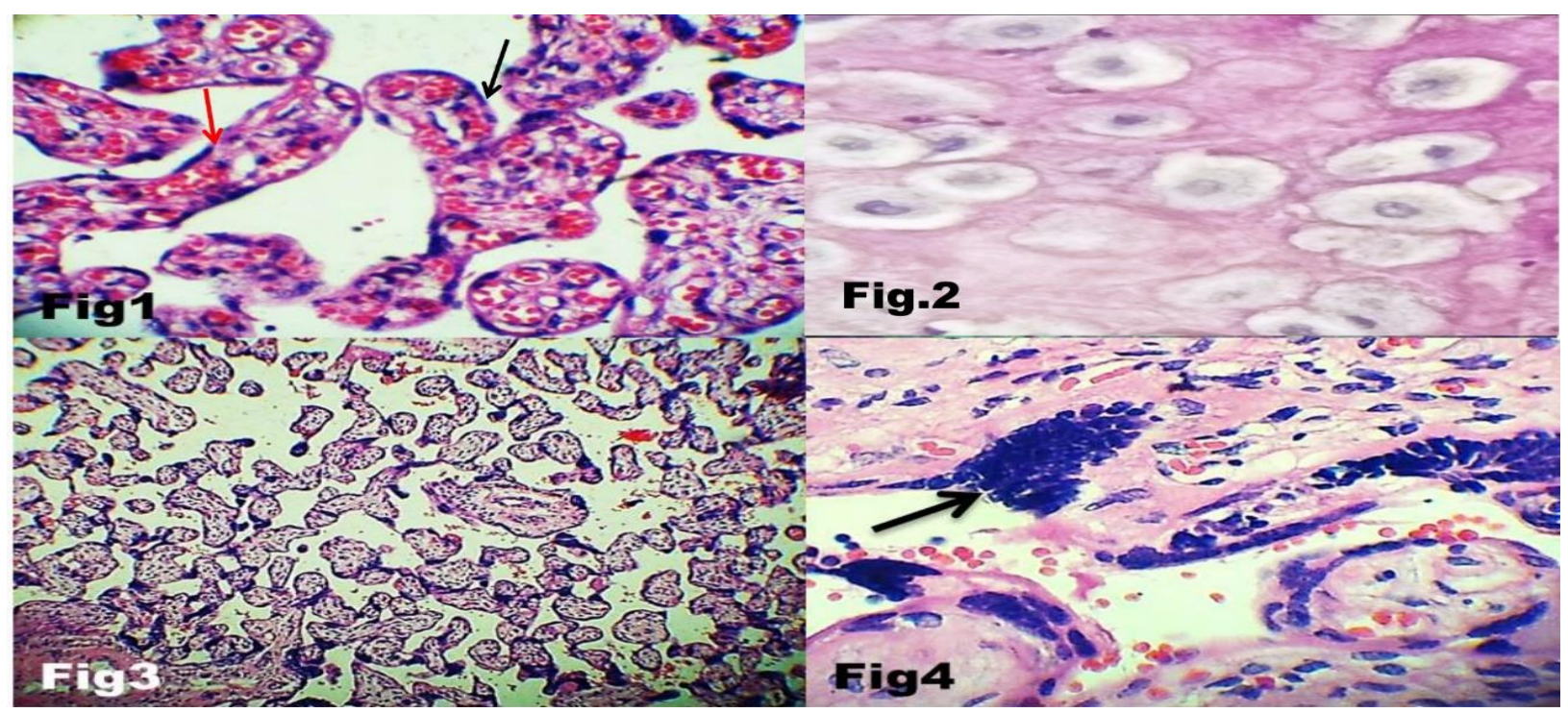

Figure 1. A photomicrograph of a placental section obtained from control group with normal architecture of villi. The vascular stroma lined with multinucleated syncytiotrophoblastic layer with indistinct cell boundaries and dark stained nuclei (black arrow) with occasional cytotrophoblastic cells (red arrow). (H\&E×250).

Figure 2. A photomicrograph of a placental section obtained from women of control group with normal architecture of decidua. (H\&E×400).

Figure 3. A photomicrograph of a placental section obtained from women of group 2 with excessive syncytial knotting in hypo-vascular villi with decreased VSM. (H\&E×100).

Figure 4. A photomicrograph of a placental section obtained from women in group 2 with excessive syncytial knotting (arrow) in hypo-vascular villi with decreased VSM. (H\&E×400).
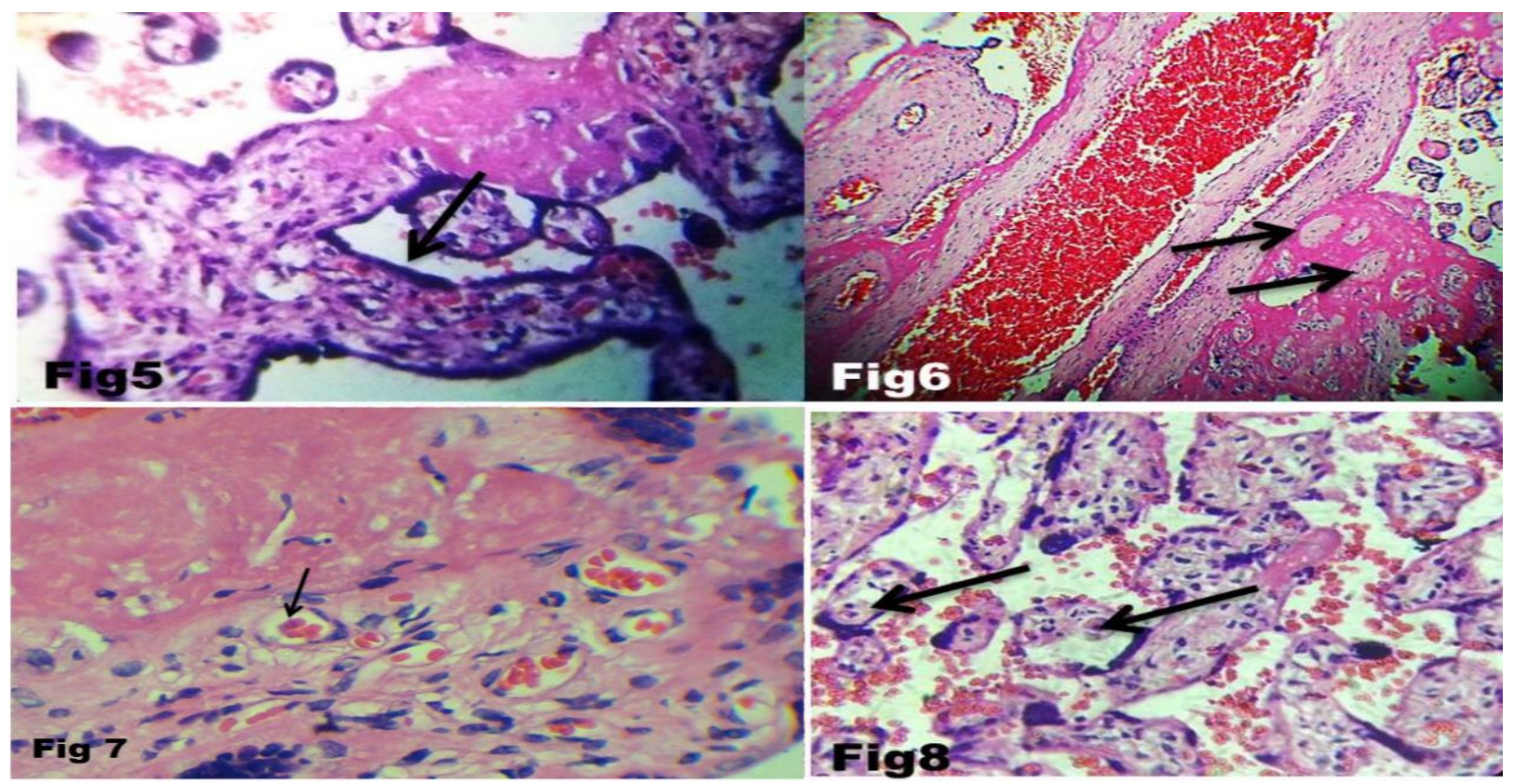

Figure 5. A photomicrograph of a placental section obtained from women of group 2 showing villous with thickening of basement membrane (arrow). (H\&Ex400).

Figure 6. A photomicrograph of a placental section obtained from women of group 2 .Fibrotic avascular villi are embedded in a sea of fibrin (perivillous fibrin deposition) (arrows). (H\&Ex100).

Figure 7. A photomicrograph of a placental section obtained from obese mother in group 2 .Fibrotic hypovascular villi with NRBC are seen (arrow). (H\&E×400).

Figure 8. A photomicrograph of a placental section obtained from women of group 2 with presence of NRBCs (arrows). (H\&Ex400). 


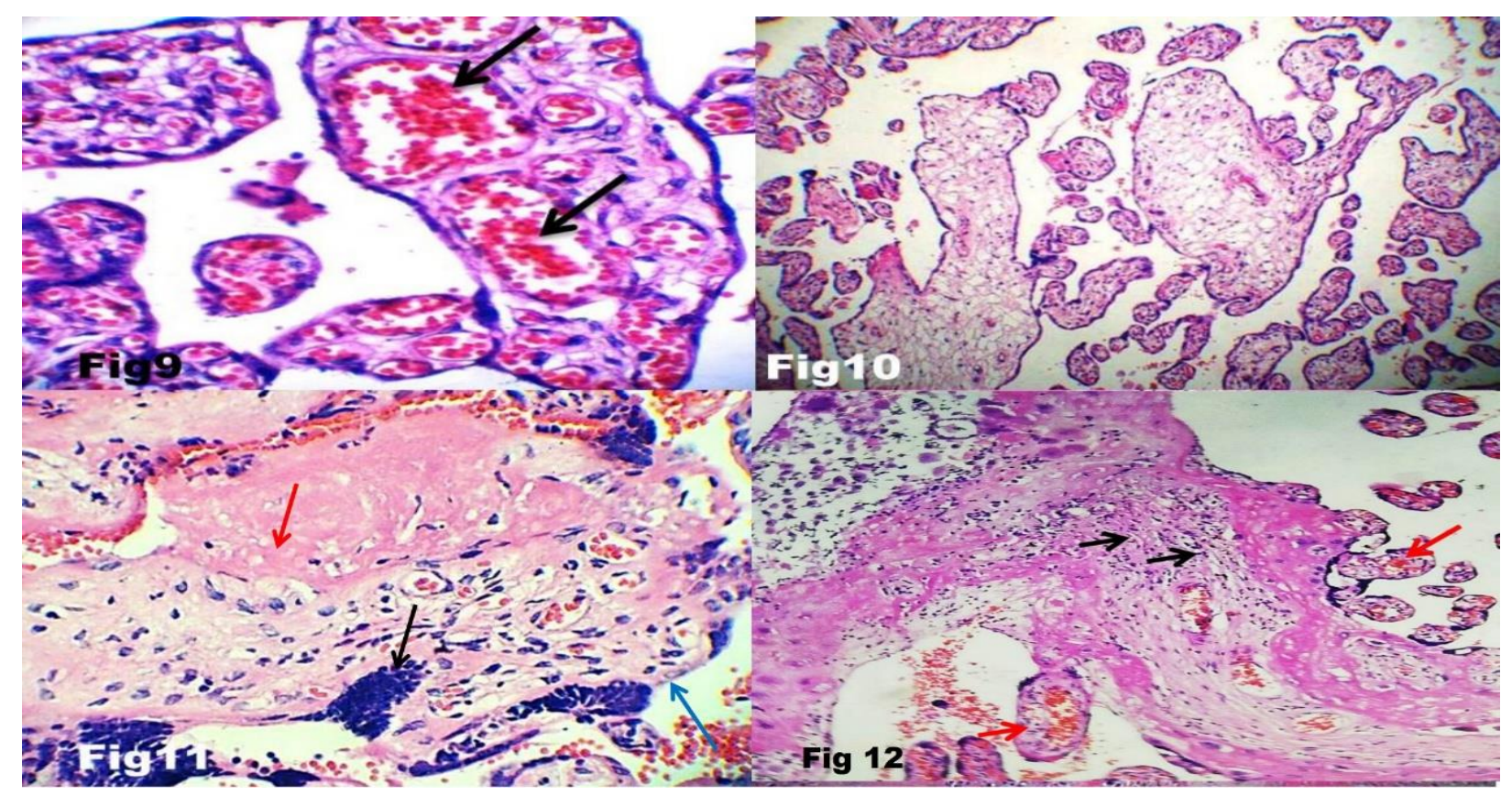

Figure 9. A photomicrograph of a placental section obtained from obese mother. Features of chorangiosis are seen (arrows). (H\&E×400).

Figure 10. A photomicrograph of aplacental section obtained from obese mother with villous oedema. (H\&E×250).

Figure 11. A photomicrograph of a placental section obtained from obese mother with features of fibrinoid necrosis (red arrow) and syncytial knotting (black arrow) in hypo vascular villi with decreased VSM (blue arrow). (H\&E×400).

Figure 12. A photomicrograph of a placental section obtained from obese mother with features of villitis (red arrow) and deciduitis (black arrow) (H\&E×250).

Table 1. Maternal characteristics in control and obese groups

\begin{tabular}{|c|c|c|c|}
\hline $\begin{array}{l}\text { Maternal } \\
\text { characteristics }\end{array}$ & $\begin{array}{c}\text { Group 1. (Control) } \\
\mathrm{N}=20(\%)\end{array}$ & $\begin{array}{c}\text { Group 2. (Obese) } \\
\mathrm{N}=20(\%)\end{array}$ & $\begin{array}{c}\text { P-Value } \\
\mathrm{P}<0.05\end{array}$ \\
\hline Age less than 35 years & $18(90 \%)^{*}$ & $12(60 \%)$ & $<0.00001$ \\
\hline Age more than 35 years & $2(10 \%)$ & $8(40 \%)^{*}$ & $<0.00001$ \\
\hline Primigravidas & $8(40 \%)^{*}$ & $0(0 \%)$ & $<0.00001$ \\
\hline Multigravidas & $12(60 \%)$ & $20(100 \%)^{*}$ & $<0.00001$ \\
\hline Normal vaginal delivery & $14(70 \%)^{*}$ & $8(40 \%)$ & 0.00002 \\
\hline Caesarean section & $6(30 \%)$ & $12(60 \%)^{*}$ & 0.00002 \\
\hline Previous abortion & $4(20 \%)$ & $10(50 \%)^{*}$ & $<0.00001$ \\
\hline
\end{tabular}


Table 2. Histological finding of placental sections

\begin{tabular}{|c|c|c|c|}
\hline Groups & $\begin{array}{l}\text { Group 1( Control) } \\
\text { N=20 } \\
\mathrm{N}(\%)\end{array}$ & $\begin{array}{l}\text { Group 2( Obese) } \\
\mathrm{N}=20 \\
\mathrm{~N}(\%)\end{array}$ & $\begin{array}{l}\text { P-Value } \\
\mathrm{P}<0.05\end{array}$ \\
\hline Histological finding & $3(15 \%)$ & $13(65 \%)^{*}$ & 0.00001 \\
\hline Syncytial knotting & $1(5 \%)$ & $10(50 \%)^{*}$ & 0.00001 \\
\hline $\begin{array}{c}\text { Hypovascular villi } \\
\text { Thickening of trophoblastic basement } \\
\text { membrane }\end{array}$ & $2(10 \%)$ & $9(45 \%)^{*}$ & 0.00001 \\
\hline Villous fibrinoid necrosis & $3(15 \%)$ & $10(50 \%)^{*}$ & 0.00001 \\
\hline Chorangiosis & $1(5 \%)$ & $4(20 \%)^{*}$ & 0.001341 \\
\hline Stromal fibrosis & $0(0 \%)$ & $8(40 \%)^{*}$ & 0.00001 \\
\hline Cytotrphoblastic hyperplasia & $0(0 \%)$ & $7(40 \%)^{*}$ & 0.00001 \\
\hline Paucity of VSM & $2(10 \%)$ & $4(35 \%)^{*}$ & 0.00023 \\
\hline Villous edema & $1(5 \%)$ & $4(20 \%)^{*}$ & 0.001341 \\
\hline Villitis & $0(0 \%)$ & $7(35 \%)^{*}$ & 0.00001 \\
\hline Deciduitis & $1(5 \%)$ & $10(50 \%)^{*}$ & 0.00001 \\
\hline Perivillous fibrin deposition & $2(10 \%)$ & $7(35 \%)^{*}$ & 0.00001 \\
\hline Nucleated RBCs & $2(10 \%)$ & 0.00023 \\
\hline
\end{tabular}

Table 3. The frequencies of placental lesions classified according to criteria of Amsterdam Placental Workshop Group

\begin{tabular}{|l|c|c|c|}
\hline $\begin{array}{l}\text { Lesions } \\
\text { types }\end{array}$ & $\begin{array}{c}\text { Groups 1. } \\
\text { Control(\%) }\end{array}$ & $\begin{array}{c}\text { Group 2. } \\
\text { Obese(\%) }\end{array}$ & $\begin{array}{c}\mathrm{P} \text {-value } \\
\mathrm{P}<0.05\end{array}$ \\
\hline Stromal- vascular lesions & $7 \%$ & $40 \%^{*}$ & $<0.00001$ \\
\hline Inflammatory lesions & $2 \%$ & $20 \%{ }^{*}$ & $<0.0001$ \\
\hline Other placental lesions & $10 \%$ & $43 \%{ }^{*}$ & $<0.00001$ \\
\hline
\end{tabular}

\section{Discussion}

The placenta is considered as the persistent Holy Grail, and a supposed record of intrauterine life that gives promise to clarify the mysteries that stand behind the adverse pregnancy outcome in several conditions including obesity. Practically, placental pathology, is finally emerging as a respectable specialty after many years of confusion related to experts with divergent views, pathologists with varying levels of interest and relevant training, and nomenclature having little relationship to either the underlying biology or clinical presentation ${ }^{26}$.

This study evaluated prospectively and systematically the histological observations of placentae of obese mothers.

Several changes were shown in placental sections of obese mothers in comparison with those of controls. A significant increase in the frequency of syncytial knots and thickening of trophoblastic basement membrane was found in placental sections of obese mothers. These observation are in accordance with other works ${ }^{28-}$ 30

That suggested these lesions may occur as a feature of placental adaptive response. The oxygen in intervillous space exchanged through terminal villi to fetal villous capillaries crosses VSM then reach fetal blood circulation ${ }^{28}$, so any increase in the thickening of VSM leads to reduction of placento-fetal blood circulation and accumulation of syncytial knots ${ }^{29}$. Moreover, Sanker et al. reported that the increase in thickness of VSM is related to accumulation of large number of high density and big diameter syncytial knots as a reflex of hypoxia ${ }^{30}$.

On the other hand, this work revealed that $10(50 \%)$ of placental sections in obese group showed features of villous hypovascularity. These findings are in accordance with those of other workers ${ }^{26,31,32}$. It has been reported that there is an increase in the frequency of abnormal modifications of the spiral arteries which lead to an alteration in the placental vascular function. On the other hand, hyperplasia of the tunica muscularis was shown in the main stem vessels of the villous tree that leads to the reduction of the blood flow in cases of obese mother ${ }^{33}$.

Villous fibrinoid necrosis was found markedly in placental sections of obese mothers in the present work. Benirscheke and Kaufmann described that this lesion may be resulted from several coagulation cascades after injury of syncytiotrophoblasts ${ }^{34}$. However, a previous study suggested that this lesion may be a sequence of accelerated villous maturation (AVM) ${ }^{26}$. The maternal vascular malperfusion and abnormal flow of spiral artery characterized by high velocity and 
low volume maternal blood. AVM represented by short hypovascular villi with increase intervillous fibrin and syncytial knots in addition to increased thickness of VSM ${ }^{35}$.

A previous study of Brouwers et al. found an increaseed AVM in the placentae of obese women. They suggested that it may be present when the rate of fetus growth is quicker than the capacity of placenta ${ }^{35}$.

This study showed a marked increase of the frequency of perivillous fibrin deposition in placental sections of obese mothers. Authors reported that this lesion is due to an increase in vessels' muscularity which lead to maternal blood stasis in intervillous space that causes coagulative reflex.

So fibrin deposition was occurred as a result of increased maternal cytokines in obese women ${ }^{(19)}$.

The light microscopic examination of placental sections of obese mothers revealed a presence of nucleated red blood cells (NRBCs). These findings are similar to those of others who suggested that fetal hypoxia in obese women lead to stimulation of an erythropoietin which in turn lead to increased NRBCs in fetal circulation of obese mothers and even in that of overweight mothers ${ }^{36,37}$, as maternal BMI was significantly correlated with their erythropoietin values.

On contrary, this work showed features of chorangiosis significantly in placental sections of obese mothers accompanied with a paucity of VSM and stromal fibrosis. In fact, villous chorangiosis occurs as a result of placental response to hypoxia ${ }^{38}$.

Moreover, Redline reported that the chorangiosis, paucity of VSM and stromal fibrosis were considered as features of delayed villous maturation (DVM) ${ }^{26,39}$ which occurs in placentae of obese mothers as a result of insulin resistance and hypoxia. Insulin resistance was more frequent in obese women which lead to increase proliferation of villi in early gestational period that lead to increased placental stroma and decreased numbers of VSM layers with increased its thickness ${ }^{40}$.

In addition, these lesions cause an inadequate oxygen diffusion and placental insufficiency ${ }^{41,42}$.In healthy placenta the functional unit was represented by dilated capillaries with perfect contact with VSM ${ }^{43}$. additionally, a study of Kaufmann et al. showed features of placentae from obese women characterized mostly by branching angiogenesis ${ }^{43}$.

On the other hand, this study found presence of villous edema in $20 \%$ of placentae of obese group which may be due to fetal vascular malperfusion and weak blood circulation in the villous tree as shown in previous works ${ }^{44,45}$.
High incidence of deciduitis and villitis was seen in placental sections of obese women. These observations were similar to those shown in other studies which reported a relation between obesity and inflammation of placenta with an increased pro-inflammatory cytokines in maternal circulation and over-production of mononuclear cells in obese mothers' blood circulation 19,46-48. A high concentrations of C-reactive protein (CRP) and interleukin-6 (IL-6) have been observed in obese women with increased insulin resistance and high concentrations of leptin 49.

Previous histological studies on placentae of obese women found the infiltration of proinflammatory macrophages ${ }^{50,51}$.

In fact, pro- and anti-inflammatory cytokines balance in any woman, is essential for normal function of placenta ${ }^{52}$. So the disturbance in this balance may lead to increased inflammation in placenta.

In conclusion, this work revealed a marked increase in the frequencies of different placental changes in obese mothers in comparison with controls. These lesions may reflect the adaptive response to protect the fetus from the harmful effect of metabolic disorder in obese mothers but it can lead to diminished nutrients and oxygen supply to fetus ${ }^{53-55}$. Further studies are recommended to clarify the exact mechanisms that stand behind these histological changes.

\section{ACKNOWLEDGMENT}

Authors would like to thank the staff and nurses at Obstetrics and Gynecology department and Neonatal Intensive Care Unit in AL-Khanssaa Maternity Teaching Hospital for their cooperation. Thanks to Dr. Luma Hazim for her help. We also grateful to assistant professor Dr. Saevan Fathil, Department of Pathology, College of Veterinary Medicine ,University of Mosul for his comments. Finally special thanks to the staff of Department of Anatomy, College of Veterinary Medicine, University of Mosul for their kind support.

\section{REFERENCES}

1.Poston L, Caleyachetty $\mathrm{R}$, Cnattingius $\mathrm{S}$, Corvalan C, Uauy R, Herring $S$ et al. Preconceptional and maternal obesity: epidemiology and health consequences. Lancet 2016;:Diabetes Endocrinol. 4(12):1025-1036.

2.Davies GA, Maxwell C, McLeod L, Gagnon R, Basso $M$, Bos $H$, et al. SOGC clinical practice guidelines:obesity in pregnancy. Int J Gyn Obstet 2010;110(2):167-173.

3. Laura I Stirrat, Rebecca M Reynolds. Effects of maternal obesity on early and long-term outcomes for offspring. Research and Reports in Neonatology. 2014; 4: 43-53. 
4.Flegal KM. Prevalence of Obesity and Trends in the Distribution of Body Mass Index among US Adults, 1999-2010. JAMA. 2012; 307:491-497

5.Al-Kubaisy, Al-Rubaey M, Al-Naggar RA, Karim $B$, Noor NAM et al. Maternal obesity and its relation with the cesarean section: A hospital based cross sectional study in Iraq. BMC Pregnancy and Childbirth. 2014;14:235.

6. Al-Twail NG, Abdulla NM, Abdul Ameer AJ. Prevalence of and factors associated with overweight and obesity among a group of Iraqi women. Eastern Mediterranean Health Journal. 2007;13 (2): 14-50-55.

7.Swidan A. Household survey. Baghdad, General Federation of Iraqi women. Nutritional status assessment of female 10-60 years. 1997

8. Nicholas LM, Morrison JL, Rattanatray L, Zhang S, Ozanne SE,McMillen IC . The early origins of obesity and insulin resistance:timing, programming and mechanisms. Int $\mathrm{J}$ Obes (Lond). 2016; 40:229-238.

9. O'Reilly JR, Reynolds RM. The risk of maternal obesity to the long-term health of the offspring. Clin Endocrinol (Oxf). 2013; 78: 9-16.

10. Dabelea D, Mayer-Davis EJ, Lamichhane AP, D'Agostino RB Jr., Liese AD, Vehik KS, et al. Association of intrauterine exposure to maternal diabetes and obesity with type 2 diabetes in youth: The search Case-Control Study. Diabetes Care. 2008; 31:1422-6.

11. Osgood ND, Dyck RF, Grassmann WK. The inter-and intragenerational impact of gestational diabetes on the epidemic of type 2 diabetes. $A m$ $J$ Public Health. 2011; 101:173-9.

12. Ryckman, KK, Borowski, K S., Parikh, N I. Saftlas AF . Pregnancy Complications and the Risk of Metabolic Syndrome for the Offspring Curr Cardiovasc Risk Rep. 2013; 7: 217

13. Torloni MR, Betrán AP, Horta BL, Nakamura $\mathrm{MU}$, Atallah AN, Moron AF, Valente $\mathrm{O}$. Prepregnancy BMI and the risk of gestational diabetes: a systematic review of the literature with meta-analysis. Obesity Reviews. 2009; 10:194-203.

14. Herrera E, Ortega-Senovilla H. Disturbances in lipid metabolism in diabetic pregnancy - Are these the cause of the problem?Best Practice \& Research Clinical Endocrinology and Metabolism 2010 August ;24 (I 4): 515-525

15. Norbert Freinkel. The Human Placenta in Diabetesand Obesity: Friend or Foe?Award Lecture Diabetes Care. 2018; 41:1362-1369

16. Oken E, Taveras EM, Kleinman KP, RichEdwards JW, Gillman MW. Gestational weight gain and child adiposity at age 3 years. Am J Obstet Gynecol. 2007; 196: 322-8.

17. Ferraro ZM, Barrowman N, Prud'homme D, Walker M, Wen SW, Rodger M et al. Excessive gestational weight gain predicts large for gestational age neonates independent of maternal body mass index. J Matern Fetal Neonatal Med. 2012; 25:538-42.

18. Brett KE, Ferraro ZM, Yockell-Lelievre J, Gruslin A, Adamo KB. Maternal-fetal nutrient transport in pregnancy pathologies: the role of the placenta. Int J Mol Sci. 2014; 15:16153-85.

19. Roberts KA, Riley SC, Reynolds RM, Barr S, Evans M, Statham A et al. Placental structure and Inflammation in pregnancies associated with obesity. Placenta. 2011; 32(3):247-254

20. O'Tierney PF, Lewis RM, McWeeney SK, Hanson MA, Inskip HM, Morgan TK et al. Immune response Gene profiles in the term placenta depend upon maternal muscle Mass. Reprod Sci. 2012; 19(10):1041-1056

21. Fitzgerald B, Kingdom J, Keating S. Distal villous hypoplasia. Diagn Histopathol. 2012; 18:195-200.

22. Fitzsimons KJ, Modder J. Setting maternity care standards for women with obesity in pregnancy. Semin Fetal Neonatal Med. 2010;15(2):100-107.

23. Houben ML, Nikkels PG, van Bleek GM, Visser GHA, Rovers MM, Kessel $\mathrm{H}$ et al. The association between intrauterine inflammation and spontaneous vaginal delivery at term: a cross-sectional study. PLoS One. 2009; 4(8):e6572.

24. Khong TY, Mooney EE, Ariel I, Balmus NCM,Boyd TK, Brundler MA et al. Sampling and definitions of placental lesions: Amsterdam placental workshop group consensus statement. Arch Pathol Lab Med. 2016; 140(7):698-713.

25. Veerbeek JH, Nikkels PG, Torrance HL, Gravesteijn J, Uiterweer ED, Derks JB et al. Placental pathology in early intrauterine growth restriction associated with maternal hypertension. Placenta. 2014; 35(9):696-701.

26. Raymond W. Redline, MD. Classification of placental lesions. Am J Obstet Gynecol. 2015;213(4):S21-S28.

27. Harris $M$ and Taylor $G$.medical statistics made easy. Martin dunitzcompany, London, UK, 2004; pp9-34

28. Huppertz B. The anatomy of the normal placenta. J Clin Pathol. 2008; 61:1296-302.

29. Gill JS, Salafia CM, Grebenkov D, Vvedensky DD. Modeling oxygen transport in human placental terminal villi. J Theor Biol. 2011; 291:3341.

30. Sankar KD, P. Bhanu PS, Kiran S, Ramakrishna BA, Shanthi V . Vasculosyncytial membrane in relation to syncytial knots complicates the placenta in preeclampsia: a histomorphometrical study; Anat Cell Biol. 2012 ; 45(2):86-91 
31. Hayward CE, Higgins L, Cowley EJ, Greenwood SL, Mills TA, Sibley CP, Wareing M. Chorionic plate arterial function is altered in maternal obesity. Placenta . 2013; 34:281-287.

32. Avagliano L, Bulfamante GP, Morabito A, Marconi AM. Abnormal spiral artery remodelling in the decidual segment during pregnancy: from histology to clinical correlation.J Clin Pathol. 2011; 64(12):1064-8. doi: 10.1136.

33. Castejón OC, López AJ. A light and scanning electron microscopy study of placental villi associated with obesity and hypertension. Electron J Biomed. 2013; 2:29.

34. Benirscheke K, Kaufmann P. Pathology of the human placenta, 4th edition .NewYork: springerVerlag; 2000.

35. Brouwers L, Franx A, Vogelvang TE, Houben ML, Rijn BBV, Nikkels PGJ. Association of Maternal Prepregnancy Body Mass Index With Placental Histopathological Characteristics in Uncomplicated Term Pregnancies; Pediatric and Developmental Pathology. 2019; 22(1) 45-52.

36. Rincón EV, Tapía MR, Yépez EH, Villasmil ER, Montilla JM, Cepeda DT, et al. Nucleated red blood cells and erythropoietin in overweight and obese pregnant womenProg Obstet Ginecol . 2019; 62(1):26-30.

37. Barak S, Mimouni FB, Stern R, Cohen N Marom R. Effect of maternal body mass index on cord blood erythropoietin concentrations. Journal of Perinatology. 2015; 35, 29-31.

38. Petersen S , Khangura R, Davydov D, Zhang Z, Sangha R . Placental Chorangiosis: Increased Risk for Cesarean Section, Case Reports in Obstetrics and Gynecology. 2017; 2017:1-5 doi.org/10.1155/2017/5610945.

39. Redline R. Distal villous immaturity. Diagn Histopathol. 2012;18:189-94.

40. Tanaka K, Yamada K, Matsushima M,Izawa T, Furukawa S, Kobayashi $Y$ et al. Increased maternal insulin resistance promotes placental growth and decreases placental efficiency in pregnancies with obesity and gestational diabetes mellitus.J Obstet Gynaecol Res. 2018;44(1):74-80.

41. Leon-Garcia SM, Roeder HA, Nelson KK, Liao $X$, Pizzo DP, Laurent L et al . Maternal obesity and sex-specific differences in placental pathology. Placenta. 2016; 38:33-40.

42. Janowiak Z, Mazerski J. New criterion of placental barrier maturity. Zentralbl Gynakol. 1992;114(6):292-295.

43. Kaufmann P, Mayhew TM, Charnock-Jones DS. Aspects of human fetoplacental vasculogenesis and angiogenesis. II. Changes during normal pregnancy. Placenta. 2004; 25:114-26.
44. Mehta R, Nanjundaswamy S, Schwarz SS, Petrova A. Neonatal morbidity and placental pathology. Indian J Pediatr. 2006; 73(1):25-28.

45. Paola I. Rosado-Yépez, Dora V. ChávezCorral, Sandra A. Reza-López, Irene LealBerumen, Ricardo Fierro-Murga, Selene Caballero-Cummings, Margarita LevarioCarrillo. Relation between pregestational obesity and characteristics of the placenta, The Journal of Maternal-Fetal and Neonatal Medicine, $2019 ; 33(20): 3425-3430$

DOI: $10.1080 / 14767058.2019 .1573222$

46. Denison FC, Roberts KA, Barr SM, Norman JE. Obesity, pregnancy, inflammation, and vascular function. Reproduction. 2010;140:373385

47. Schmatz M, Madan J, Marino T, Davis J. Maternal obesity. the interplay between inflammation, mother and fetus. J Perinatol, 2010; 30:441-446

48. Stewart FM, Freeman DJ, Ramsay JE, Greer IA, Caslake M, Ferrell WR. Longitudinal assessment of maternal endothelial function and markers of inflammation and placental function throughout pregnancy in lean and obese mothers. J Clin Endocrinol Metab. 2007; 92:969975

49. Ramsay JE, Ferrell WR, Crawford L, Wallace AM, Greer IA,Sattar N. Maternal obesity is associated with dysregulation of metabolic, vascular, and inflammatory pathways. J Clin Endocrinol Metab. 2002; 87:4231-4237

50. Challier JC, Basu S, Bintein T, Minium J, Hotmire K, CatalanoPM, Hauguel-de Mouzon S. Obesity in pregnancy stimulates macrophage accumulation and inflammation in the placenta.Placenta. 2008; 29:274-281

51. Roberts VH, Smith J, McLea SA, Heizer AB, Richardson JL, Myatt L. Effect of increasing maternal body mass index on oxidative and nitrative stress in the human placenta. Placenta. 2009; 30:169-175

52. Bowen JM, Chamley L, Keelan JA, Mitchell MD . Cytokines of the placenta and extraplacental membranes: roles and regulation during human pregnancy and parturition. Placenta. 2002; 23:257-273.

53. Pantham $P$, Aye IL, Powell TL. Inflammation in maternal obesity and gestational diabetes mellitus. Placenta. 2015; 36:709-15.

54. Al- Allaf LIK, Jarjees MTT, Al- Nuaimy WMT. Histological Changes of Human Placenta in Prolonged Pregnancy. J Bah Med Soci. 2008; 20(2):60-67.

55. Al- Allaf LIK. Histological Changes of Human Placenta of Preterm Birth. J Bah Med Soci. 2010; 4:151-156 